\title{
Involvement of Voltage-Gated Sodium Channel Nav1.8 in the Regulation of the Release and Synthesis of Substance $P$ in Adult Mouse Dorsal Root Ganglion Neurons
}

\author{
He-Bin Tang ${ }^{1}$, Eri Shiba ${ }^{1}$, Yu-Sang Li $^{2}$, Norimitsu Morioka ${ }^{1}$, Tai-Xing Zheng ${ }^{3}$, Nobukuni Ogata ${ }^{3}$, \\ and Yoshihiro Nakata ${ }^{1, *}$ \\ ${ }^{I}$ Department of Pharmacology, Graduate School of Biomedical Sciences, Hiroshima University, \\ Kasumi 1-2-3, Minami-ku, Hiroshima 734-8553, Japan \\ Departments of ${ }^{2}$ Pathology and ${ }^{3}$ Neurophysiology, Graduate School of Biomedical Sciences, Hiroshima University, \\ Kasumi 1-2-3, Minami-ku, Hiroshima 734-8551, Japan.
}

Received June 24, 2008; Accepted August 15, 2008

\begin{abstract}
This study was conducted to determine whether $\mathrm{Na}_{\mathrm{v}} 1.8$ contributes to the release and/or synthesis of substance P (SP) in adult mice dorsal root ganglion (DRG) neurons. The SP released from cultured DRG neurons of $\mathrm{Na}_{\mathrm{v}} 1.8$ knock-out mice exposed to either capsaicin or $\mathrm{KCl}$ was significantly lower than that from wild-type $(\mathrm{C} 57 \mathrm{BL} / 6)$ mice based on a radioimmunoassay. The SP level of L6 DRG in $\mathrm{Na}_{\mathrm{v}} 1.8$ knock-out mice was also lower than that in wild-type mice. After chronic constriction injury (CCI) of the sciatic nerve, the level of SP decreased in the L6 ipsilateral DRG of wild-type but not $\mathrm{Na}_{\mathrm{v}} 1.8$ knock-out mice. The preprotachykinin-A (PPT-A) mRNAs in L4 - 6 DRGs of $\mathrm{Na}_{\mathrm{v}} 1.8$ knock-out mice also fell to half their normally abundant levels of expression. There were significant increases in $\mathrm{Na}_{\mathrm{v}} 1.8$ expression of the L6 contralateral DRG from wild-type mice and in the percentage of neurons expressing neurokinin-1 receptor in the cytosol of L6 DRGs from wild-type or $\mathrm{Na}_{\mathrm{v}} 1.8$ knock-out mice. These findings suggest that $\mathrm{Na}_{\mathrm{v}} 1.8$ is involved in the regulation of the release and synthesis of SP in the DRG neurons of wild-type mice.
\end{abstract}

Keywords: dorsal root ganglion (DRG), chronic constriction injury (CCI), $\mathrm{Na}_{\mathrm{v}} 1.8$ knock-out mice, preprotachykinin-A (PPT-A) mRNA, substance P (SP)

\section{Introduction}

$\mathrm{Na}_{\mathrm{v}} 1.8$, a tetrodotoxin-resistant voltage-gated sodium $\left(\mathrm{Na}_{\mathrm{v}}\right)$ channel, is an integral membrane protein that conducts sodium ions through the plasma membrane to produce the rising phase of an action potential $(1-3)$. The primary afferent nerves expressing $\mathrm{Na}_{\mathrm{v}} 1.8$ contribute to the abnormal conduction of sensory information following neuropathy, facilitating repetitive firing in the dorsal root ganglion (DRG) upon sensory stimulation $(4-7)$. Based on the distribution and pathophysiology of $\mathrm{Na}_{\mathrm{v}} 1.8$, several studies have demonstrated the involvement of $\mathrm{Na}_{\mathrm{v}} 1.8$ in the transmission of nociceptive

*Corresponding author. ynakata@hiroshima-u.ac.jp Published online in J-STAGE on October 9, 2008 (in advance) doi: $10.1254 /$ jphs.08163FP and neuropathic pain messages. For example, treatment with a specific antisense oligodeoxynucleotide blocking this channel reduces the neuropathic pain caused by spinal nerve ligation in rats (8). In addition, a potent and selective $\mathrm{Na}_{\mathrm{v}} 1.8$ sodium channel blocker (A-803467) has been shown to attenuate both neuropathic and inflammatory pain in rats $(9,10)$.

Substance P (SP) is a tachykinin neuropeptide wellknown for its function as an important neurotransmitter and/or primary afferent modulator to relay the pain message to nerves leading to the spinal cord and brain. In particular, it plays a critical role in communicating chronic pain information from the periphery to the central nervous system (11). SP, encoded by the preprotachykinin-A (PPT-A) gene, is synthesized in the DRG and released from primary afferent neurons to convey information about various noxious stimuli 
through a complex process $(12-16)$. However, it is not known whether the complex process of SP release and/or the SP synthesis requires the regulation of $\mathrm{Na}_{\mathrm{v}} 1.8$ in DRG neurons. It is therefore of interest to investigate the possible relationship between $\mathrm{Na}_{\mathrm{v}} 1.8$ and the release and synthesis of SP in DRG neurons.

The present study used a highly sensitive radioimmunoassay, immunofluorescence staining, and realtime PCR techniques to examine whether $\mathrm{Na}_{\mathrm{v}} 1.8$ is involved in the regulation of capsaicin- and $\mathrm{KCl}$-evoked SP release from cultured mice DRG neurons and to identify the potential relationship between $\mathrm{Na}_{\mathrm{v}} 1.8$ and the SP synthesis in DRG neurons of mice with or without a chronic constriction injury $(\mathrm{CCI})$ of the sciatic nerve.

\section{Materials and Methods}

\section{Isolation of DRGs and culture of DRG neurons}

Either adult male C57BL/6 wild-type or $\mathrm{Na}_{\mathrm{v}} 1.8$ knock-out mice (kindly provided by Dr. Nobukuni Ogata, ref. 17) were divided into two groups, respectively. After the two groups were decapitated, the spinal cord sections were separated from the bodies, and DRGs attached to the spinal cords were aseptically picked up and harvested. The isolated L4 - 6 DRGs from group I were directly used to examine the SP level and the PPTA mRNA expression. According to a previously described method (12), the isolated DRGs (four regions: cervical, thoracic, lumbar, and sacral DRGs) of wildtype and $\mathrm{Na}_{\mathrm{v}} 1.8$ knock-out mice (6-9 weeks of age) from group II were dissociated into single isolated neurons and non-neuronal cells. The cultures were maintained at $37^{\circ} \mathrm{C}$ in a water-saturated atmosphere with $5 \% \mathrm{CO}_{2}$ for 5 days before the initiation of the experiments. All animal procedures were performed in accordance with the Guide for Animal Experimentation, Hiroshima University and the Committee of Research Facilities for Laboratory Animal Sciences, Graduate School of Biomedical Sciences, Hiroshima University. The deletion of $\mathrm{Na}_{\mathrm{v}} 1.8$ in the $\mathrm{Na}_{\mathrm{v}} 1.8$ knock-out mice was confirmed by a previously described patch-clamp technique (17).

\section{Measurement of the SP content}

Except for some cultured cells treated with peptidase inhibitors alone (as a control), other cultured cells were exposed to capsaicin (10 to $1,000 \mathrm{nM})$ or $\mathrm{KCl}$ (30 and $50 \mathrm{mM})$ in $1 \mathrm{ml} \mathrm{Krebs-HEPES} \mathrm{buffer}(110 \mathrm{mM} \mathrm{NaCl}$, $4.5 \mathrm{mM} \mathrm{KCl}, 2 \mathrm{mM} \mathrm{CaCl}, 1.2 \mathrm{mM} \mathrm{MgSO}, 1.2 \mathrm{mM}$ $\mathrm{KH}_{2} \mathrm{PO}_{4}, 25 \mathrm{mM} \mathrm{NaHCO}, 11.7 \mathrm{mM}$ D-glucose, $5 \mathrm{mM}$ HEPES) containing peptidase inhibitors $(1 \mu \mathrm{M}$ phosphoramidon, $4 \mu \mathrm{g} / \mathrm{ml}$ bacitracin and $1 \mu \mathrm{M}$ captopril;
Sigma Chemical Co., St. Louis, MO, USA) for $10 \mathrm{~min}$ at $37^{\circ} \mathrm{C}$. Thereafter, the SP content collected from the Krebs-HEPES buffer was measured using a highly sensitive radioimmunoassay with a polyclonal antibody specific to the C-terminus of SP (12). Alternatively, either the total SP content collected from untreated cultured DRG neurons of wild-type or $\mathrm{Na}_{\mathrm{v}} 1.8$ knock-out mice and their respective culture medium [horse serumcontaining Dulbecco's modified Eagle's medium (DMEM; Nissui Pharmaceutical, Tokyo)] or the SP content collected from lumbar DRGs of wild-type and $\mathrm{Na}_{\mathrm{v}} 1.8$ knock-out mice was lyophilized and then assayed by a radioimmunoassay.

\section{Real-time PCR for determining PPT-A mRNA expres- sion}

Total RNA harvested from the L4-6 DRGs of mice by the acid guanidinium thiocyanate-phenolchloroform extraction method was separately subjected to reverse transcription into cDNA using a Superscript kit (Life Technologies, Gaithersburg, MD, USA) according to the manufacturer's protocol. Thereafter, $2 \mu \mathrm{g}$ of cDNA sample was used immediately in a real-time PCR assessment of PPT-A mRNA levels with iQ SYBR Green Supermix (Bio-Rad, Tokyo) and forward primer (5'-GGTGCCAACGATGATCT-3') and reverse primer (5'-GCATCCCGTTTGCCCATT-3') on a DNA engine Opticon 2 real-time PCR detection system (Bio-Rad). The thermal cycler parameters were as follows: 1 cycle of $3 \mathrm{~min}$ at $95^{\circ} \mathrm{C}$, followed by 40 cycles of $15 \mathrm{~s}$ at $95^{\circ} \mathrm{C}$, $30 \mathrm{~s}$ at $60^{\circ} \mathrm{C}$, and $30 \mathrm{~s}$ at $72^{\circ} \mathrm{C}$. A glyceraldehyde-3phosphate dehydrogenase (GAPDH) control was run simultaneously with the same reaction recipe listed in the instruction manual for the iQ SYBR Green Supermix (Bio-Rad). All data were normalized to the GAPDH mRNA levels to account for any variation in RNA concentrations between the samples obtained from 4 separate experiments.

\section{Preparation of mouse sciatic nerve CCI model}

After wild-type and $\mathrm{Na}_{\mathrm{v}} 1.8$ knock-out mice were anaesthetized with trichloroacetaldehyde monohydrate (450 mg/kg i.p.; Wako, Osaka), the left or right sciatic nerves were exposed at the mid-thigh portion, two ligatures of 4-0 chromic gut (Ethichon, Brussels, Belgium) were tied loosely around these nerves (18); the contralateral sciatic nerves were exposed but not manipulated. For sham-operated control mice, the sciatic nerves were exposed similarly but not manipulated. At three days after surgery, the plantar surfaces of the hind paws were probed by a series of 6 von Frey filaments (ranging from 0.16 to $2 \mathrm{~g}$ force). The CCI surgery produced a decrease in the mechanical pain threshold 
one week after loose ligation of the sciatic nerve and this phenomenon continued for approximately one month (data not shown). To isolate the lumbar DRGs, all mice were killed two weeks after the surgeries.

\section{Immunofluorescence staining}

The isolated lumbar DRGs from these sham-operated and CCI model mice were embedded in paraffin blocks. Next, 4- $\mu$ m-thick sections were cut and mounted on glass microslides (Matsunami, Osaka). The paraffinembedded sections were deparaffinized in xylene and then rehydrated through a graded ethanol series to water. The sections were then washed twice in $10 \mathrm{mM}$ phosphate-buffered saline (PBS) containing $0.1 \%$ Triton $\mathrm{X}-100$ (Sigma) and incubated for $60 \mathrm{~min}$ at room temperature with rabbit anti-SP receptor $(1: 2,000$ dilution; Sigma) alone or rabbit anti-Na $\mathrm{v}_{\mathrm{v}} 1.8$ antibody (1:500 dilution; Alomone Labs, Jerusalem, Israel) plus mouse anti-MAP-2 primary antibody (1:200 dilution; Chemicon, Temecula, CA, USA) in PBS containing $1 \%$ BSA and $0.1 \%$ Triton X-100 (14), followed by washing twice with PBS and incubation for $60 \mathrm{~min}$ at room temperature with Alexa Fluor 546 goat anti-rabbit IgG (1:1,000 dilution; Molecular Probes, Eugene, OR, USA) alone or Alexa Fluor 488 goat anti-rabbit IgG (1:1,000 dilution, Molecular Probes) plus Alexa Fluor 546 goat anti-mouse IgG (1:1,000 dilution, Molecular Probes). Finally, the sections were washed three times in PBS and visualized by a fluorescent microscope (Biozero BZ8000; Keyence, Osaka). Quantification of $\mathrm{Na}_{\mathrm{v}} 1.8$ immunofluorescence was performed with the use of image analysis software (VH Analyzer, Keyence) from 3 separate experiments. For the quantification in each experiment, two equal-sized fields of each photograph per group were randomly chosen.

\section{Statistics}

The data are each presented as the mean \pm S.E.M. Statistical analyses were performed by the multiple $t$-test with the Bonferroni correction following ANOVA. Significance was set at a value of $P<0.05$ (two-tailed).

\section{Results}

The release and total content of SP from cultured DRG neurons

Figure 1, a and b, show a dose-dependence of SP release induced by either capsaicin $(10$ to $1,000 \mathrm{nM})$ or $\mathrm{KCl}(30$ and $50 \mathrm{mM})$ from cultured DRG neurons. A gradual increase in either the capsaicin $(10$ to $100 \mathrm{nM})$ or $\mathrm{KCl}(30$ and $50 \mathrm{mM}$ )-evoked SP release from cultured DRG neurons of either wild-type or $\mathrm{Na}_{\mathrm{v}} 1.8$ knock-out mice was observed, whereas either the capsaicin- or
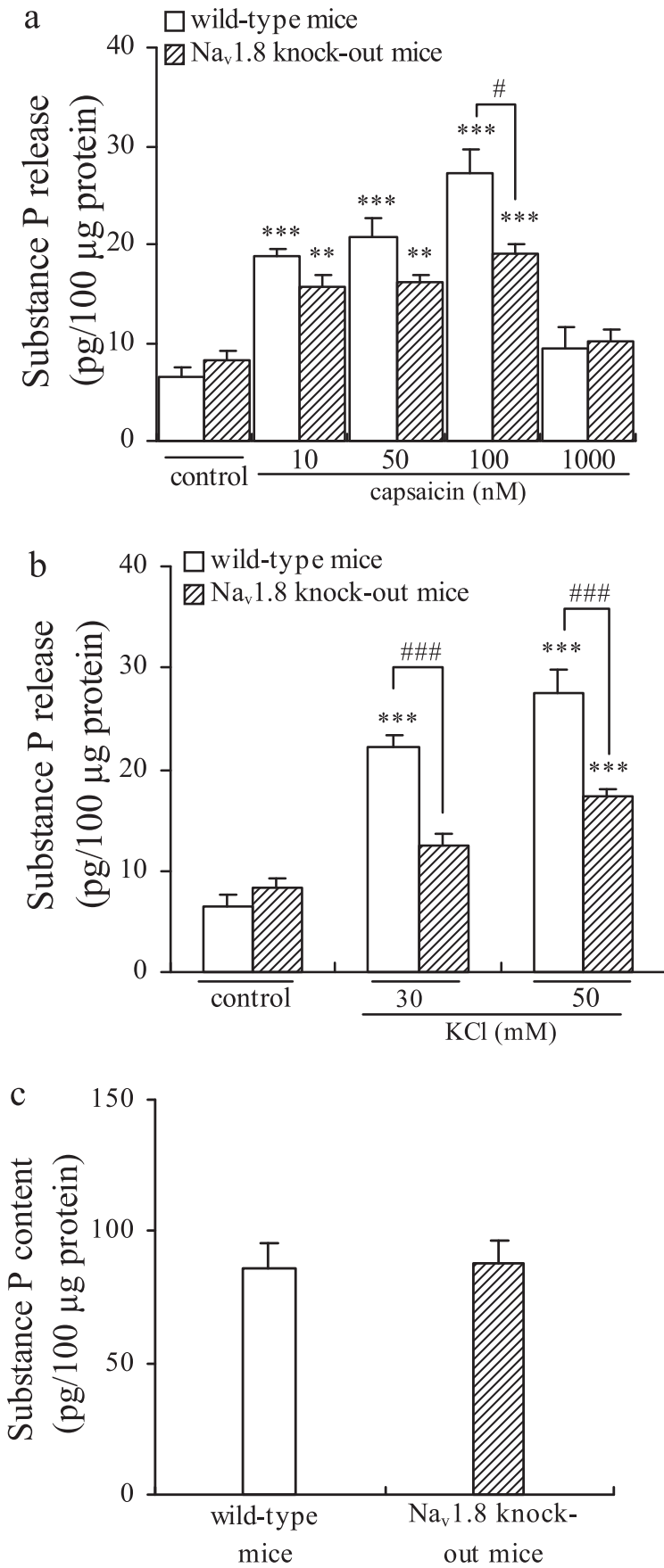

Fig. 1. Release and content of SP from cultured DRG neurons of either wild-type or $\mathrm{Na}_{\mathrm{v}} 1.8$ knock-out mice. The dose-dependent effects of capsaicin (a) and $\mathrm{KCl}$ (b) on the SP release from cultured DRG neurons of either wild-type or $\mathrm{Na}_{\mathrm{v}} 1.8$ knock-out mice. c: The SP content in untreated cultured DRG neurons of either wild-type or $\mathrm{Na}_{\mathrm{v}} 1.8$ knock-out mice. The data were obtained from $3-5$ (a), 4 (b), or 4 (c) separate experiments. ${ }^{\#} P<0.05$ and ${ }^{\# \# \#} P<0.001$. ${ }^{* *} P<0.01$ and $* * * P<0.001$ versus the corresponding control from either wild-type or $\mathrm{Na}_{\mathrm{v}} 1.8$ knock-out mice.

KCl-evoked response of SP release from the cultured DRG neurons of $\mathrm{Na}_{\mathrm{v}} 1.8$ knock-out mice was weaker than that from wild-type mice. A high concentration of 
Table 1. The levels of SP in the L4 - 6 DRGs from control and CCI operated mice

\begin{tabular}{|c|c|c|c|c|c|c|}
\hline \multirow[b]{3}{*}{ DRG } & \multicolumn{3}{|c|}{ Wild-type mice } & \multicolumn{3}{|c|}{$\mathrm{Na}_{\mathrm{v}} 1.8$ knock-out mice } \\
\hline & \multirow[b]{2}{*}{ sham } & \multicolumn{2}{|c|}{ CCI } & \multirow[b]{2}{*}{ sham } & \multicolumn{2}{|c|}{ CCI } \\
\hline & & ipsilateral & contralateral & & ipsilateral & contralateral \\
\hline L4 & $83 \pm 7$ & $50 \pm 4$ & $56 \pm 11$ & $78 \pm 6$ & $76 \pm 10$ & $64 \pm 5$ \\
\hline L5 & $93 \pm 6$ & $68 \pm 16$ & $69 \pm 2$ & $83 \pm 13$ & $65 \pm 4$ & $61 \pm 4$ \\
\hline L6 & $233 \pm 5^{\mathrm{a}, \mathrm{b}, \mathrm{c}}$ & $179 \pm 14^{\mathrm{a}, \mathrm{d}}$ & $273 \pm 8^{\mathrm{a}}$ & $151 \pm 15^{\mathrm{a}, \mathrm{e}}$ & $196 \pm 14^{\mathrm{a}}$ & $185 \pm 25^{\mathrm{a}, \mathrm{e}}$ \\
\hline
\end{tabular}

The data are each expressed as the mean \pm S.E.M. (pg/DRG) of $3-6$ mice; ${ }^{\text {a }} P<0.01$, compared to the corresponding L4 - 5 DRGs of mice; ${ }^{\mathrm{b}} P<0.05$ and ${ }^{\mathrm{d}} P<0.01$, compared to the contralateral L6 DRG of wild-type mice; ${ }^{\mathrm{c}} P<0.05$, compared to the ipsilateral L6 DRG of wild-type mice; ${ }^{\mathrm{e}} P<0.01$, compared to the corresponding lumbar DRG of wild-type mice.

capsaicin $(1 \mu \mathrm{M})$ induced a lower level of SP release from cultured DRG neurons of either wild-type or $\mathrm{Na}_{\mathrm{v}} 1.8$ knock-out mice, which seems to be a consequence of TRPV1 (transient receptor potential vanilloid receptor subtype 1) desensitization (16). Next, it was observed that there was no difference in terms of total SP content between the two kinds of mice (Fig. 1c).

$S P$ content in the isolated lumbar DRGs of wild-type and $N a_{v} 1.8$ knock-out mice with or without CCI

To examine the SP level which reflects the release and synthesis of SP in the L4-6 DRG in both wild-type and $\mathrm{Na}_{\mathrm{v}} 1.8$ knock-out mice, the CCI model mice were prepared to analyze the SP content by using a polyclonal antibody specific to C-terminus of SP. The SP content of L4 - 6 in wild-type mice (naive) was first compared to those of sham-operated wild-type. There was no difference in the SP level of L4-6 (data not shown), therefore the data obtained from sham-operated wildtype mice was regarded as those of wild-type mice (naive). As shown in Table 1, the SP level in L6 DRG $(233 \pm 5 \mathrm{pg} / \mathrm{DRG})$ of sham-operated wild-type mice was approximately 2.5 -fold greater in comparison to the L4 (83 $\pm 7 \mathrm{pg} / \mathrm{DRG})$ and L5 (93 $\pm 6 \mathrm{pg} / \mathrm{DRG})$ DRGs, which was the most abundant among the L4-6 DRGs. In $\mathrm{Na}_{\mathrm{v}} 1.8$ knock-out mice, a similar result was observed and the SP level in L6 DRG $(151 \pm 15 \mathrm{pg} / \mathrm{DRG})$ of sham-operated $\mathrm{Na}_{\mathrm{v}} 1.8$ knock-out mice was approximately 1.8 -fold greater in comparison to the L4 (78 $\pm 6 \mathrm{pg} / \mathrm{DRG})$ and L5 (83 $\pm 13 \mathrm{pg} / \mathrm{DRG})$ DRGs.

Interestingly, the CCI of the sciatic nerve with wildtype mice produced a significant decrease of the SP level in ipsilateral L6 DRG $(179 \pm 14 \mathrm{pg} / \mathrm{DRG})$ and induced a significant increase of the SP level in the contralateral L6 DRG (273 $\pm 8 \mathrm{pg} / \mathrm{DRG})$ in comparison to L6 DRG $(233 \pm 5 \mathrm{pg} / \mathrm{DRG})$ of sham-operated wild-type mice. The CCI of the sciatic nerve also led to a relative decrease in the SP level of either ipsilateral $(50 \pm 4$ $\mathrm{pg} / \mathrm{L} 4 \mathrm{DRG}, 68 \pm 16 \mathrm{pg} / \mathrm{L} 5 \mathrm{DRG})$ or contralateral (56 $\pm 11 \mathrm{pg} / \mathrm{L} 4 \mathrm{DRG}, 69 \pm 2 \mathrm{pg} / \mathrm{L} 5$ DRG) L4-5 DRGs of wild-type mice in comparison to the corresponding lumbar DRGs (83 \pm 7 pg/L4 DRG, $93 \pm 6$ pg/L5 DRG) of sham-operated wild-type mice (see Table 1).

Similar alterations in the SP levels of either ipsilateral $(76 \pm 10 \mathrm{pg} / \mathrm{L} 4 \mathrm{DRG}, 65 \pm 4 \mathrm{pg} / \mathrm{L} 5 \mathrm{DRG})$ or contralateral $(64 \pm 5 \mathrm{pg} / \mathrm{L} 4 \quad \mathrm{DRG}, 61 \pm 4 \mathrm{pg} / \mathrm{L} 5 \quad \mathrm{DRG})$ L4 - 5 DRGs of $\mathrm{Na}_{\mathrm{v}} 1.8$ knock-out mice were observed in comparison to the corresponding lumbar DRGs (78 $\pm 6 \mathrm{pg} / \mathrm{L} 4 \mathrm{DRG}, 83 \pm 13 \mathrm{pg} / \mathrm{L} 5 \mathrm{DRG})$ of shamoperated $\mathrm{Na}_{\mathrm{v}} 1.8$ knock-out mice (see Table 1). However, there was no significant alteration in the SP levels between ipsilateral and contralateral L6 DRGs of $\mathrm{Na}_{\mathrm{v}} 1.8$ knock-out mice with CCI, in comparison to the shamoperated $\mathrm{Na}_{\mathrm{v}} 1.8$ knock-out mice.

PPT-A mRNA expression in the lumbar DRGs of wildtype and $N a_{v} 1.8$ knock-out mice with or without CCI

Unlike the distribution pattern of the SP levels in those lumbar DRGs, the PPT-A mRNA expressions in the L4-6 DRGs of $\mathrm{Na}_{\mathrm{v}} 1.8$ knock-out mice were approximately 1.5-, 3-, and 2-fold higher than those in the corresponding lumbar DRG of wild-type mice, respectively (Fig. 2a). After a CCI of the sciatic nerve of $\mathrm{Na}_{\mathrm{v}} 1.8$ knock-out mice, lower levels of PPT-A mRNA expression were observed in the L4-6 DRGs in comparison to the corresponding lumbar DRGs of sham-operated mice (Fig. 2b). Furthermore, the levels of PPT-A mRNA expression in the ipsilateral $(46 \%, 38 \%$, and $47 \%$ for L4, L5, and L6 in comparison to L4 of sham-operated mice, respectively) lumbar DRGs of $\mathrm{Na}_{\mathrm{v}} 1.8$ knock-out mice were more lower than in the corresponding contralateral $(62 \%, 52 \%$, and $88 \%$ for $\mathrm{L} 4$, L5 and L6 compared to L4 of sham-operated mice, respectively) lumbar DRGs (Fig. 2b). These data suggest the CCI of the sciatic nerve induced the DRG to enhance the intra-dorsal root ganglionic SP release in lumbar DRGs. 
a



b



Fig. 2. PPT-A mRNA expression in the L4-6 lumbar DRGs. a: The PPT-A mRNA expression in the lumbar DRGs of wild-type and $\mathrm{Na}_{\mathrm{v}} 1.8$ knock-out mice. $\mathrm{b}$ : The down-regulation of PPT-A mRNA expression in the lumbar DRGs of $\mathrm{Na}_{\mathrm{v}} 1.8$ knock-out mice after the CCI of the sciatic nerve. The data were obtained from either 4 (a) or 4 (b) separate experiments. ${ }^{\#} P<0.05,{ }^{\#} P<0.01$, and ${ }^{\# \#} P<0.001$.

\section{Expression of $N a_{v} 1.8$ and $N K-1 R$ in the L6 DRGs by immunohistochemistry}

To estimate the intra-dorsal root ganglionic release of $\mathrm{SP}$, the levels of NK-1R in the L6 DRG of wild-type mice with or without CCI of the sciatic nerve were quantified. Since activation of the NK-1R by SP triggers SP release in cultured adult rat DRG neurons with NK$1 \mathrm{R}$ internalization (14), the numbers of DRG neurons expressing NK-1R protein in their cytosols were quantified by immunohistochemistry. As shown in Fig. 3d, after the CCI of the sciatic nerve, an increase was observed in the percentage of neurons expressing NK-1R in the cytosol of these neurons of either the ipsilateral $(79 \pm 13 \%$ for wild-type mice or $72 \pm 13 \%$ for $\mathrm{Na}_{\mathrm{v}} 1.8$ knock-out mice) or contralateral L6 DRGs ( $78 \pm 2 \%$ for wild-type mice or $73 \pm 4 \%$ for $\mathrm{Na}_{\mathrm{v}} 1.8$ knock-out mice) from wild-type or $\mathrm{Na}_{\mathrm{v}} 1.8$ knock-out mice with CCI (Fig. 3d) in comparison to their respective shams ( $23 \pm 2 \%$ for wild-type mice or $30 \pm 4 \%$ for $\mathrm{Na}_{\mathrm{v}} 1.8$ knock-out mice), thus suggesting an augmenta- tion of intra-dorsal root ganglionic SP release in both L6 in response to the sciatic nerve ligation. In the present study, the ratio of the number of neurons expressing the NK-1R in the cytosol to the total number of NK-1Rpositive neurons in a randomly selected field in each image from three separate experiments was simultaneously calculated from digitally merged photomicrographs of bright-field and immunofluorescent images of NK-1R expressions. The immunofluorescent photomicrographs (Fig. 3b) of the sham indicate the DRG neurons where the NK-1Rs are mainly expressed on their membranes, but there is very little or no NK-1R expression in the cytosol of these neurons. Other photomicrographs (red) of CCI indicate the DRG neurons where the NK-1Rs are expressed on their membranes and in the cytosol.

The expression of $\mathrm{Na}_{\mathrm{v}} 1.8$ protein (Fig. $3 \mathrm{c}$ ) tended to increase in the ipsilateral L6 DRGs $(123 \pm 13 \%)$ after the CCI of the sciatic nerve of wild-type mice, whereas it significantly increased in the contralateral L6 DRGs $(212 \pm 12 \%)$, in comparison to the L6 DRGs $(100 \pm 13 \%)$ of sham. These data suggest that $\mathrm{Na}_{\mathrm{v}} 1.8$ protein could be necessary to regulate SP release in L6 DRG.

\section{Discussion}

The current approach was intended to determine a possible correlation between $\mathrm{Na}_{\mathrm{v}} 1.8$ and the release and/or synthesis of SP in mouse DRG neurons. For the first time, L6 DRG was demonstrated to have the most abundant amount of SP among the lumber DRGs. This was also the first study to show that $\mathrm{Na}_{\mathrm{v}} 1.8$ plays important roles in contributing to the regulation of SP release from DRG neurons and the synthesis of SP in the L6 DRG of mice.

In the absence of a well-established blocker of $\mathrm{Na}_{\mathrm{v}} 1.8$, DRG neurons from $\mathrm{Na}_{\mathrm{v}} 1.8$ knock-out mice were used to examine changes in the levels of SP release and its total content in vitro and in vivo. During a 5-day period of primary culture, there was no difference in the morphological changes and the number of DRG neurons from either wild-type or $\mathrm{Na}_{\mathrm{v}} 1.8$ knock-out mice (data not shown). Although, there was no difference in the total amount of SP in cultured DRG neurons from wild-type or $\mathrm{Na}_{\mathrm{v}} 1.8$ knock-out mice (Fig. 1c), the cultured DRG neurons from wild-type mice exhibited a higher SP release response to two potent stimulators $(\mathrm{KCl}$ and capsaicin) than those from $\mathrm{Na}_{\mathrm{v}} 1.8$ knock-out mice (Fig. 1: $\mathrm{a}$ and $\mathrm{b}$ ). These data suggest that $\mathrm{Na}_{\mathrm{v}} 1.8$ could be involved in the release of SP from DRG neurons when stimulated by capsaicin or $\mathrm{KCl}$. Furthermore, $\mathrm{Na}_{\mathrm{v}} 1.8$ might not be involved in the storage of SP in DRG 
a

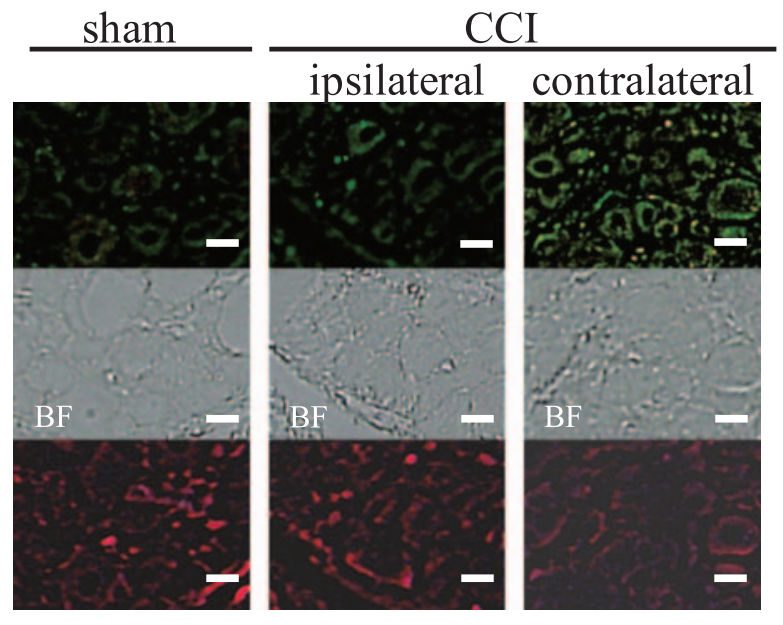

c

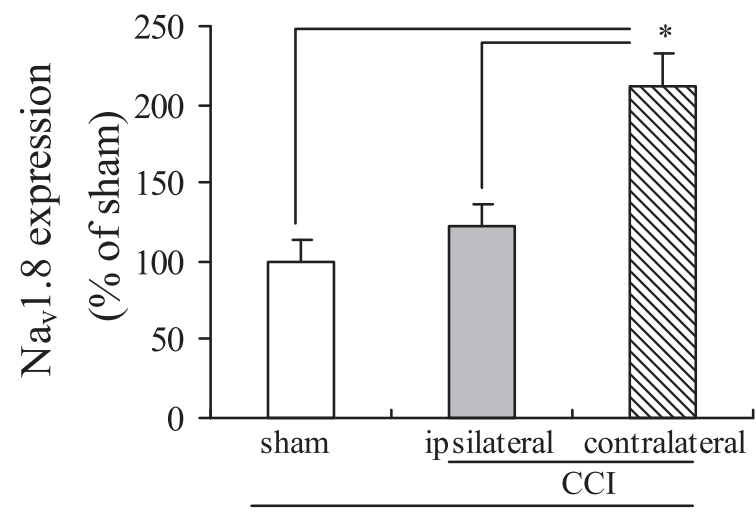

wild-type mice b

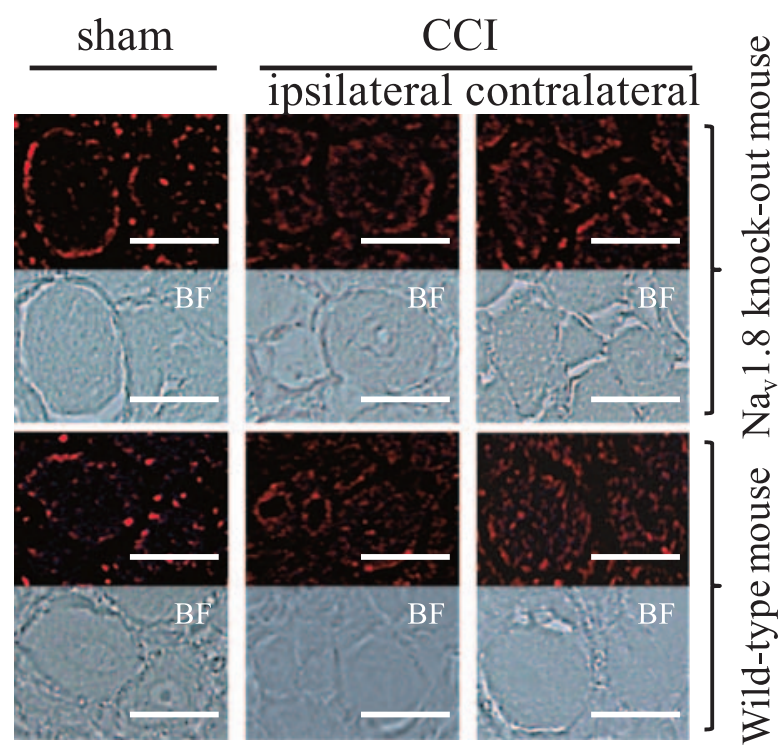

d

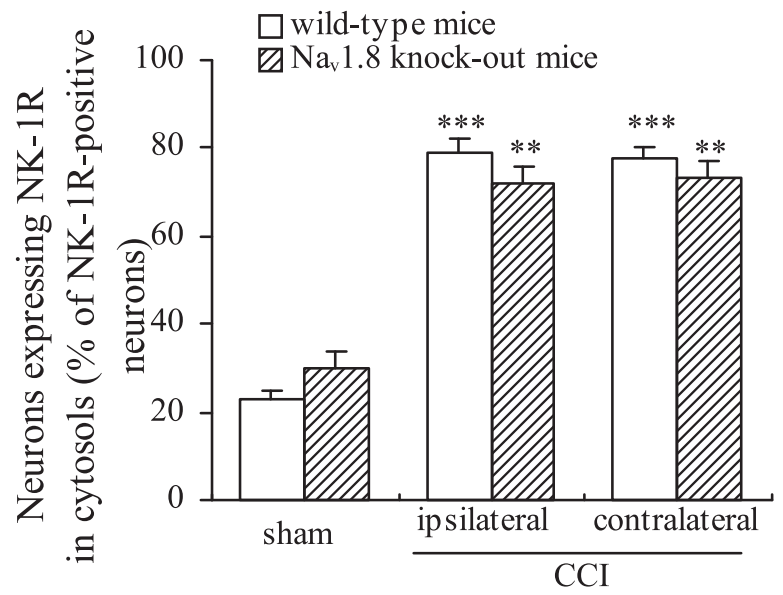

Fig. 3. Expression of $\mathrm{Na}_{\mathrm{v}} 1.8$ protein and localization of NK-1R. a: Representative photomicrographs of $\mathrm{Na}_{\mathrm{v}} 1.8$ (green, upper panels) and MAP-2 (red, lower panels) immunofluorescence in L6 DRGs of wild-type mice with or without CCI. b: NK-1R expression in L6 DRGs. BF: bright-field photomicrograph. Scale bars: $30 \mu \mathrm{m}$. c: Quantification of $\mathrm{Na}_{\mathrm{v}} 1.8$ expression from panel a. d: Counting of neurons expressing NK-1R in the cytosol from panel b. ${ }^{*} P<0.05,{ }^{*} P<0.01$, and ${ }^{* * *} P<0.001$ versus the corresponding sham from either wild-type or $\mathrm{Na}_{\mathrm{v}} 1.8$ knock-out mice.

neurons. However, the possibility of the loss of the $\mathrm{Na}_{\mathrm{v}} 1.8$ activity during the 5-day period of primary culture could not be ruled out.

Alternatively, the present study indicated that the level of SP in the L6 DRGs was the most abundant in the corresponding L4-6 DRGs of wild-type or $\mathrm{Na}_{\mathrm{v}} 1.8$ knock-out mice. The phenomenon of the abundant SP in the L6 DRG may be interpreted to reflect the type of innervations in the organs because the SP-immunoreactive neurons in L6 DRG of rats may be involved in the transmission of nociception in rat penile frenulum (19). Interestingly, the SP level of L6 DRG in the sham- operated wild-type mice was much greater in comparison to that in the sham-operated $\mathrm{Na}_{\mathrm{v}} 1.8$ knock-out mice (Table 1). This suggests that $\mathrm{Na}_{\mathrm{v}} 1.8$ might be involved in the upregulation of localized biosynthesis of SP in L6 DRG of mice. To test this hypothesis, a CCI of the sciatic nerve was applied to two kinds of mice to examine the intra-dorsal root ganglionic SP release. There is extensive data on the expression of PPT-A mRNA (20) or $\mathrm{Na}_{\mathrm{v}} 1.8$ function (21) in DRG neurons after peripheral nerve injury. In the present study, the PPT-A mRNAs in the lumbar DRGs of the $\mathrm{Na}_{\mathrm{v}} 1.8$ knock-out mice with CCI also fell to half their normally 


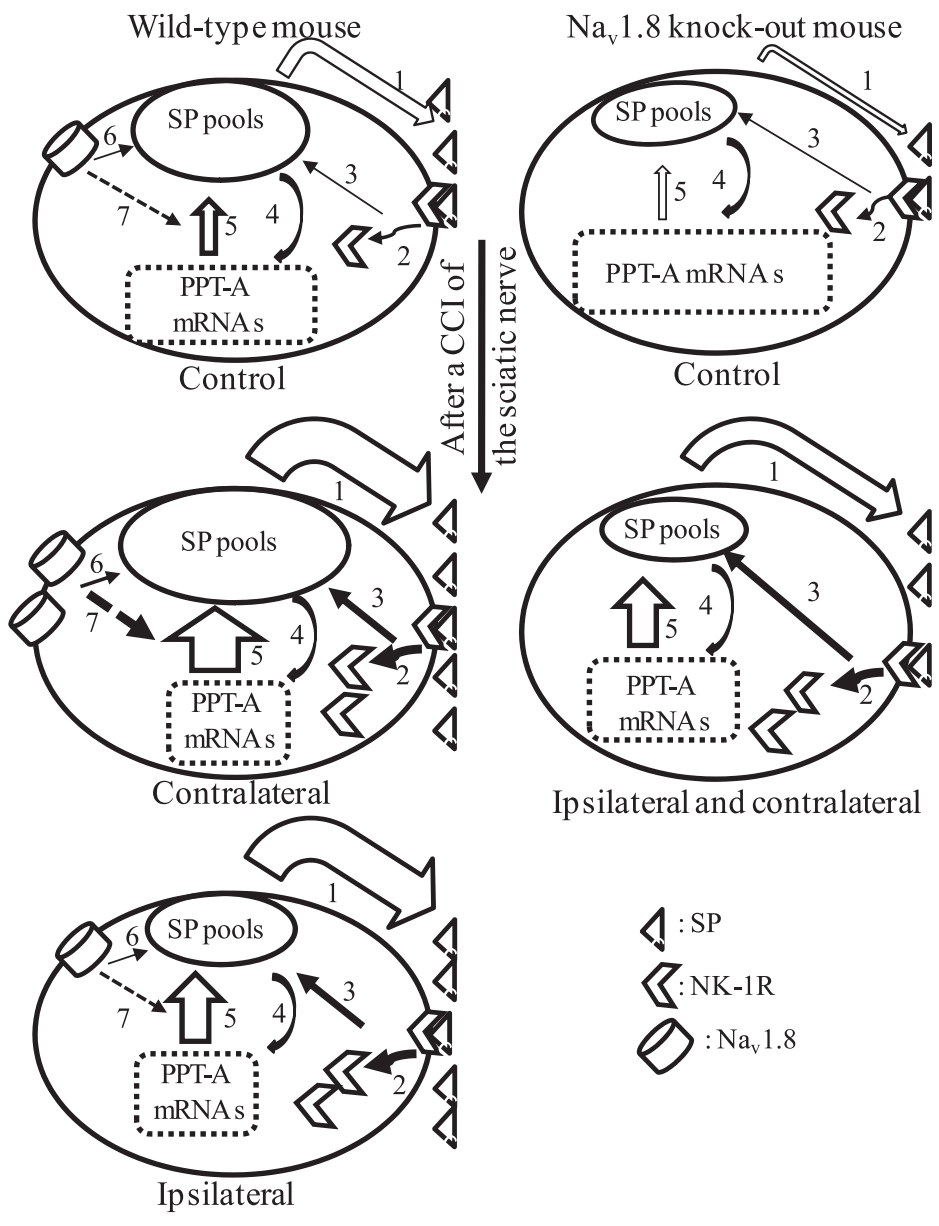

Fig. 4. A schematic diagram showing the possible points of the relationships between the release and synthesis of SP and the Nav1.8 expression in L6 DRG. 1: SP release from intracellular SP pools of DRG neurons. 2: The released SP binds to the NK-1R, resulting in internalization of the SP-NK-1R complex. 3: The internalization of NK-1R elicits a signal to further release the SP. 4: Following the reduction of SP level in intracellular SP pools evoked by the released SP, a signal will be elicited to convey information for increasing the SP synthesis. 5: The decreased level of SP in intracellular SP pools may stimulate the synthesis of SP, which probably leads to a decrease in the PPT-A mRNA level in DRG neuron. 6: $\mathrm{Na}_{\mathrm{v}} 1.8$ may be involved in the enhancement of SP release. 7: $\mathrm{Na}_{\mathrm{v}} 1.8$ might be involved in the enhancement of the signal to further release the SP. The CCI of the sciatic nerve induces the increases in some responses including points 1,2 and 3,5 and 6, and 7. The width of each arrow and the area of each box indicate the relative level of activity elicited in each step. abundant levels of expression, which is similar to an observation of Nahin et al. (20). SP is derived directly from the transcripts of nuclear PPT-A genes and it is synthesized on ribosomes. Thereafter, it is stored in socalled large dense core vesicles (LDCVs) in DRG neurons to be released in response to various noxious stimuli for conveying nociceptive information. In addition, the CCI of the sciatic nerve induced the NK-1R internalization in small diameter DRG neurons of both wild-type and $\mathrm{Na}_{\mathrm{v}} 1.8$ knock-out mice, and thus significantly increased the expression level of $\mathrm{Na}_{\mathrm{v}} 1.8$ in the contralateral L6 DRGs of wild-type mice. The internalization of NK-1R is now considered to be an important index of endogenous SP release $(14,22-26)$. During the internalization of NK-1R, the SP/NK1-R complex dissociates in acidified endosomes. SP is degraded, whereas the NK1-R recycles to the cell surface (27). Based on our results and the observations described above, we herein propose in Fig. 4 the possible molecular mechanisms underlying the relationships among the SP content amount and its mRNA level and $\mathrm{Na}_{\mathrm{v}} 1.8$ expression in the L6 DRG during the sciatic nerve injury. These indicate the hyper-SP release from these lumbar DRGs during the sciatic nerve injury. Therefore the reduction of the SP level in the ipsilateral L6 DRGs from wild-type mice with CCI should also be partially considered to be a consequence of hyper-SP release. The increase of the SP level in the contralateral L6 DRGs of wild-type mice with CCI seems to be associated with the significant increase of the $\mathrm{Na}_{\mathrm{v}} 1.8$ expression in the contralateral L6 DRGs. However, further studies will be necessary to elucidate the exact mechanism by which DRG neurons of $\mathrm{Na}_{\mathrm{v}} 1.8$ knock-out mice exert their distinct characteristics in the inhibition of release and synthesis of SP, for example, to investigate effects of the potent and selective $\mathrm{Na}_{\mathrm{v}} 1.8$ sodium channel blocker A803467 (9) on the release and localized synthesis of SP from the DRG neurons of wild-type mice.

In summary, the deletion of $\mathrm{Na}_{\mathrm{v}} 1.8$ attenuates the noxious stimuli-induced response of SP release from DRG neurons and also contributes to a decrease in the localized synthesis of SP in the L6 DRG of mice. These observations provide more evidence to understand the relationship between $\mathrm{Na}_{\mathrm{v}} 1.8$ sodium channels and $\mathrm{SP}$ in primary afferent neurons. 


\section{Acknowledgments}

We thank Dr. Asao Noda and Dr. Yuko Hirai, Radiation Effects Research Foundation, Hiroshima, for the use of fluorescent microscope system. This study was supported by a Grant-in-Aid for Scientific Research (B) from the Japan Society for the Promotion of Science (JSPS) to H.B. Tang (No. 19790189).

\section{References}

1 Renganathan M, Cummins TR, Waxman SG. Contribution of $\mathrm{Na}_{\mathrm{v}} 1.8$ sodium channels to action potential electrogenesis in DRG neurons. J Neurophysiol. 2001;86:629-640.

2 Djouhri L, Fang X, Okuse K, Wood JN, Berry CM, Lawson SN. The TTX-resistant sodium channel $\mathrm{Na}_{\mathrm{v}} 1.8$ (SNS/PN3): expression and correlation with membrane properties in rat nociceptive primary afferent neurons. J Physiol. 2003;550:739-752.

3 Renganathan M, Gelderblom M, Black JA, Waxman SG. Expression of $\mathrm{Na}_{\mathrm{v}} 1.8$ sodium channels perturbs the firing patterns of cerebellar Purkinje cells. Brain Res. 2003;959:235242.

4 Akopian AN, Sivilotti L, Wood JN. A tetrodotoxin-resistant voltage-gated sodium channel expressed by sensory neurons. Nature. 1996;379:257-262.

5 Rush AM, Bräu ME, Elliott AA, Elliott JR. Electrophysiological properties of sodium current subtypes in small cells from adult rat dorsal root ganglia. J Physiol. 1998;511:771-789.

6 Blair NT, Bean BP. Role of tetrodotoxin-resistant $\mathrm{Na}^{+}$current slow inactivation in adaptation of action potential firing in smalldiameter dorsal root ganglion neurons. J Neurosci. 2003;23: 10338-10350.

7 Beyak MJ, Ramji N, Krol KM, Kawaja MD, Vanner SJ. Two TTX-resistant $\mathrm{Na}+$ currents in mouse colonic dorsal root ganglia neurons and their role in colitis-induced hyperexcitability. Am J Physiol Gastrointest Liver Physiol. 2004;287:G845-G855.

8 Lai J, Gold MS, Kim CS, Bian D, Ossipov MH, Hunter JC, et al. Inhibition of neuropathic pain by decreased expression of the tetrodotoxin-resistant sodium channel, $\mathrm{Na}_{\mathrm{v}} 1.8$. Pain. 2002;95: $143-152$.

9 Jarvis MF, Honore P, Shieh CC, Chapman M, Joshi S, Zhang $\mathrm{XF}$, et al. A-803467, a potent and selective $\mathrm{Na}_{\mathrm{v}} 1.8$ sodium channel blocker, attenuates neuropathic and inflammatory pain in the rat. Proc Natl Acad Sci U S A. 2007;104:8520-8525.

10 Zimmermann K, Leffler A, Babes A, Cendan CM, Carr RW, Kobayashi J, et al. Sensory neuron sodium channel $\mathrm{Na}_{\mathrm{v}} 1.8$ is essential for pain at low temperatures. Nature. 2007;447:855858.

11 De Koninck Y, Henry JL. Substance P-mediated slow excitatory postsynaptic potential elicited in dorsal horn neurons in vivo by noxious stimulation. Proc Natl Acad Sci U S A. 1991;88:1134411348.

12 Tang HB, Inoue A, Oshita K, Hirate K, Nakata Y. Zaltoprofen inhibits bradykinin-induced responses by blocking the activation of second messenger signaling cascades in rat dorsal root ganglion cells. Neuropharmacology. 2005;48:1035-1042.

13 Tang HB, Inoue A, Iwasa M, Hide I, Nakata Y. Substance P release evoked by capsaicin or potassium from rat cultured dorsal root ganglion neurons is conversely modulated with bradykinin. J Neurochem. 2006;97:1412-1418.

14 Tang HB, Li YS, Arihiro K, Nakata Y. Activation of the neurokinin-1 receptor by substance $P$ triggers the release of substance $\mathrm{P}$ from cultured adult rat dorsal root ganglion neurons. Mol Pain. 2007;3:42.

15 Tang HB, Li YS, Nakata Y. The release of substance P from cultured dorsal root ganglion neurons requires the non-neuronal cells around these neurons. J Pharmacol Sci. 2007;105:264-271.

16 Tang HB, Nakata Y. The activation of transient receptor potential vanilloid receptor subtype 1 by capsaicin without extracellular $\mathrm{Ca}^{2+}$ is involved in the mechanism of distinct substance $\mathrm{P}$ release in cultured rat dorsal root ganglion neurons. Naunyn Schmiedebergs Arch Pharmacol. 2008;377:325-332.

17 Zheng T, Kakimura J, Matsutomi T, Nakamoto C, Ogata N. Prostaglandin $\mathrm{E}_{2}$ has no effect on two components of tetrodotoxin-resistant $\mathrm{Na}^{+}$current in mouse dorsal root ganglion. $\mathrm{J}$ Pharmacol Sci. 2007;103:93-102.

18 Bennett GJ, Xie YK. A peripheral mononeuropathy in rat that produces disorders of pain sensation like those seen in man. Pain. 1988;33:87-107.

19 Wu ZM, Ni JJ, Ling SC. Substance P and/or calcitonin generelated peptide immunoreactive neurons in dorsal root ganglia possibly involved in the transmission of nociception in rat penile frenulum. Zhonghua Nan Ke Xue. 2007;13:1068-1071.

20 Nahin RL, Ren K, De León M, Ruda M. Primary sensory neurons exhibit altered gene expression in a rat model of neuropathic pain. Pain. 1994;58:95-108.

21 Gold MS, Weinreich D, Kim CS, Wang R, Treanor J, Porreca F, et al. Redistribution of $\mathrm{Na}_{\mathrm{v}} 1.8$ in uninjured axons enables neuropathic pain. J Neurosci. 2003;23:158-166.

22 Nathan JD, Patel AA, McVey DC, Thomas JE, Prpic V, Vigna $\mathrm{SR}$, et al. Capsaicin vanilloid receptor-1 mediates substance $\mathrm{P}$ release in experimental pancreatitis. Am J Physiol Gastrointest Liver Physiol. 2001;281:G1322-G1328.

23 Allen BJ, Li J, Menning PM, Rogers SD, Ghilardi J, Mantyh PW, et al. Primary afferent fibers that contribute to increased substance $\mathrm{P}$ receptor internalization in the spinal cord after injury. J Neurophysiol. 1999;81:1379-1390.

24 Trafton JA, Abbadie C, Basbaum AI. Differential contribution of substance $\mathrm{P}$ and neurokinin A to spinal cord neurokinin-1 receptor signaling in the rat. J Neurosci. 2001;21:3656-3664.

25 Marvizón JC, Grady EF, Stefani E, Bunnett NW, Mayer EA. Substance $\mathrm{P}$ release in the dorsal horn assessed by receptor internalization: NMDA receptors counteract a tonic inhibition by GABA(B) receptors. Eur J Neurosci. 1999;11:417-426.

26 Nakatsuka T, Mena N, Ling J, Gu JG. Depletion of substance P from rat primary sensory neurons by ATP, an implication of P2X receptor-mediated release of substance P. Neuroscience. 2001;107:293-300.

27 Grady EF, Garland AM, Gamp PD, Lovett M, Payan DG, Bunnett NW. Delineation of the endocytic pathway of substance $P$ and its seven-transmembrane domain NK1 receptor. Mol Biol Cell. 1995;6:509-524. 